\begin{tabular}{|c|c|}
\hline \multirow{3}{*}{ 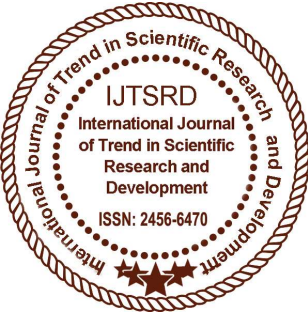 } & $\begin{array}{l}\text { International Journal of Trend in Scientific } \\
\text { Research and Development (IJTSRD) }\end{array}$ \\
\hline & International Open Access Journal \\
\hline & ISSN No: 2456 - 6470 | www.ijtsrd.com | Volume - 1 | Issue - 5 \\
\hline
\end{tabular}

\title{
Connecting Financial Performance of Firms with Merger and Acquisitions through Review of Literature: A Global Perspective
}

\author{
Asif Amin Kuchey \\ $\mathrm{PhD}$ scholar at Al-Falah University
}

\author{
Dr. Anisa Jan \\ Senior Assistant Professor at Islamic University of \\ Science and Technology
}

\begin{abstract}
This paper tries to examine and combine literature of M\&A and its effect on financial performance of firms. It also tries to identify those factors that affect the financial performance of acquirer or target firms. A comprehensive review of literature is carried out to determine factors used to evaluate pre and post M\&A performance. The review has been carried out on accounting measures-based studies and market measures-based studies done at both national as well as in-ternational level. The main aim of the review is to analyze the link between M\&A and financial performance of the firms. This paper concludes that the effect of merger and acquisition varies from sector to sector. This paper also shows inconclusive results regarding effect of cross border M\&A and domestic $M \& A$ on the financial performance of the firms.
\end{abstract}

Keywords: M\&A, acquirer, target, financial performance, Cross-Border, domestic

\subsection{Introduction}

Merger and acquisition has become a new strategy in the corporate world. Companies are using M\&A mainly for exploring new markets, reap high market share, gaining competency and to become more competitive in the global market. This activity can take place by acquisition, merger, joint ventures, takeovers, collaborations, and diversification. The post globalization period has led firms from emerging markets to become more aggressive in pursuit of merger and acquisition in order to fight the competitive battle. A lot of firms find that the best way to get ahead is to expand ownership boundaries through mergers and acquisitions. Moreover M\&A create synergies, gain economies of scale, expand operations, increase sales and cut costs. Investors may expect mergers to deliver enhanced market power. It is no secret that plenty of mergers do not work. Those who favor mergers will argue that the merger will cut costs or boost revenues by more than enough to justify the price premium. Well in theory, M\&A is great, but in reality, things can go wrong. Empirical results reveal that many of mergers were disappointed, where the motivations that drive mergers can be weak and efficiencies from economics of scale may prove hard to find.

\subsection{Need of the study}

Due to globalization and technological changes firms are facing stiff competition. To face these challenges and explore opportunities, firms are going for inorganic growth through various strategic alternatives like merger and acquisition (M\&A). The purpose of this study is to establish a link between the financial performance of the firms with their merger and acquisition activity. Thus, this paper tries to get insight regarding the impact of M\&A on financial performances of the firm. The impact could be positive, negative or neutral on various sectors. This study also tries to identify the key financial parameters that can be used to carry out future research.

\subsection{Objectives of the study}

i. To review the impact of M\&A on financial performance of different sectors. 
International Journal of Trend in Scientific Research and Development (IJTSRD) ISSN: 2456-6470

ii. To identify the key factors that impacts the financial performance of firms before and after M\&As.

\subsection{Review of Literature}

Abbas et al. ${ }^{1}$ analyzed the financial performance before and after merger and acquisition in banking sector of Pakistan. The financial and accounting data for 10 banks was taken from the Financial Statement Analysis by State Bank of Pakistan. Profitability \& Efficiency, Leverage, and Liquidity ratios were used to measure the financial performance, where pre and post ratio analysis was done. The outcome of their study showed that there was no improvement in the financial performance of banks after M\&A. There was decrease in profitability, efficiency, liquidity, and leverage ratio(s) in most of the banks. Additionally HSBC Bank Middle East Limited and Dubai Banking Group LLC showed increase in their financial performance after M\&A in most of the ratio(s). In the dimension of liquidity and leverage, there was no much improvement in the ratio(s) of these banks. Finally they concluded that overall there was a negative improvement in the financial performance of banks in Pakistan after M\&A.

Anand and Singh ${ }^{2}$ investigated the impact of mergers in Indian banking sector on the shareholders wealth. The investigation was based on specific five mergers in Indian banking sector namely Times bank with HDFC, the Bank of Madura with the ICICI Bank, the ICICI Ltd with the ICICI Bank, the Global Trust Bank with the Oriental Bank of Commerce, and the Bank of Punjab with the Centurion Bank. The merger announcements have positive and significant effect on shareholders wealth both for bidder and target banks. The market value Weighted cumulative average returns(WCAR) of the combined bank portfolio as a result of merger announcement is 4.29 $\%$ in a three day period $(-1,1)$ window and $9.71 \%$ in a eleven day period $(-5,5)$ event window. The findings of the study are in agreement with the European and the US bank Mergers and acquisitions except for the fact that the value to the share holders of bidder banks has been wiped out in the US context.

Beena ${ }^{3}$ evaluated the pre and post merger period performance of firms in the Indian pharmaceutical industry. The pre-merger analysis ranged from 198990 to the year of first merger or acquisition of each merging firm. The period from the time of first merger or acquisition to 2003-2004 was considered for the post merger analysis. The relative firm level performance of the merging firms was also attempted. For this, each merging firms' averages (from the respective ratios) for the pre and post merger period was calculated which revealed the comparative performance across firms before and after merger. The number of firms remained above average in terms of profitability, cost intensity and trade performance remained more or less same during the post merger period whereas that of $R \& D$ intensity showed that many firms newly entered into the upper strata, which shows nothing other than technological progress. In the case of export and import intensity, a slightly reverse trend occurred. Moreover, many of the firms could increase their profitability compared to their own pre merger period except for Return on Net Worth. Around 78 percent of the firms increased their R\&D spending and 74 percent of them reduced the advertisement expenditure. The most striking point was that, around 91 percent of the firms were underutilizing their capacity compared to their own past. She concluded that the overall performance of the merging firms increased during the post merger period as compared to the pre-merger period. However, she also observed that many of the merging firms were falling below average. Therefore she rightly stated that the post-merger profitability of the merging firms is higher than that of the pre-merger period performance.

Beena ${ }^{4}$ evaluated the pre and post merger performance of a sample of 115 acquiring firms in the manufacturing sector in India between 1995 - 2000 using various key accounting drivers and t-test. The research consisted of 84 domestically owned acquiring firms and 31 foreign-owned acquiring firms involved in M\&As. The performance has been measured in terms of price-cost margin, ROR, shareholder's profit, dividend per equity and debtequity ratio, etc. She concluded that the study could not find any conclusive evidence of improvement in the financial ratios during the post merger period as compared to the pre merger period for the acquiring firms.

Berg et al ${ }^{5}$ carried a inclusive cross-firm and crossindustry analysis to measure the effect of joint venture activities on the performance of the companies and found ambiguous but positive short-term gains and insignificant long-term impact on profitability. They further noted that even short-term gains were negative 
International Journal of Trend in Scientific Research and Development (IJTSRD) ISSN: 2456-6470

for technological based acquisitions and were positive for production and marketing based acquisitions, because of increased market power leading to increased profit margins and efficiency gains. They concluded that while short term gains depend on industry to industry, no industry (out of 19 industries in their sample) show long-term significant gain.

Choi and Russell ${ }^{6}$ inspected whether mergers and acquisitions in the construction sector in U.S made positive contributions to the performance and determined the factor that may affect post-mergers and acquisitions performance as method of payment, acquisition timing and transaction size. The study reviewed 171 transactions between 1980-2002 using Cumulative abnormal returns (CAR) to indicate improvement in performance. Their analysis revealed that there was insignificant improvement in performance.

Cornett, McNutt and Tehranian ${ }^{7}$ examined the operating performance of commercial bank mergers. They found that industry adjusted operating performance of selected merged banks increased significantly after the merger, large bank mergers produced greater performance gains than small bank mergers, activity focusing mergers showed better performance better then activity diversifying mergers, geographically focusing mergers produce better performance then geographically diversifying mergers, and performance gains were larger after the implementation of nationwide banking in 1997. Further, they concluded that improved performance was the result of both revenue enhancements and cost reduction activities.

Gugler et al. ${ }^{\mathbf{8}}$ analyzed the effects of mergers around the world over the past 15 years. They utilized a large panel of data on mergers to test several hypotheses about mergers. The effects of the mergers are examined by comparing the performance of the merging firms with control groups of non merging firms. The comparisons are made on profitability and sales. The results showed that mergers on average do result in significant increases in profits, but reduced the sales of the merging firms. They also found similarities in the post merger patterns across countries. They have separated mergers into those that increase profits and those that reduce them and by then examining the patterns of sales changes following the mergers; they determined the effects of mergers on efficiency and market power. Their results suggested that those mergers that decrease profits and efficiency account for a large proportion. However, they have also identified mergers that increase profits by either increasing market power or by increasing efficiency. The first conclusion seems to be a more likely explanation for large companies, whereas the latter is likely to be true for small firms

Healy, Palepu, and Ruback ${ }^{9}$ evaluated postacquisition performance of 50 outsized mergers in U.S between 1979 and 1984 by measuring the cash flow performance. They proposed that acquiring firms might benefit from merging because of technical, monetary and diversification synergies. They pointed out that merged firms have significant improvement in asset productivity relative to their industries after the merger, leading to higher post merger operating cash flow returns. Sample firms maintain their capital expenditure and $R \& D$ rates relative to their industries after the merger, showing that merged firms do not reduce their long-term investments. They also found that there is a strong positive relation between post merger increase in operating cash flows and abnormal stock returns at merger announcements, indicating that expectations of economic improvements trigger the equity revaluations of the merging firms. They concluded that operating performance of merging firms improved significantly following acquisitions, when compared to their respective industries.

Indhumathi et al. ${ }^{10}$ evaluated a sample of companies which went through merger during the period of 2002-2005. They compared the performance of the acquirer and target companies before and after the period of mergers by using ratio analysis and t-test during the study period of three years. They concluded that the shareholders of the acquirer companies increased their financial performance after the merger event.

Ismail et al. ${ }^{11}$ examined mergers and acquisitions and its effects on the financial performance and they ascertained factors that might influence post-mergers and acquisitions performance. They determine that there was a disagreement regarding the factors that affect the reported performance, where eight factors might affect performance as follows method of payment (Cash or Stock), book to market ratio, type of merger or acquisition transaction (related or unrelated), cross-border versus domestic M\&A, mergers versus tender offers, firm size, macro economic conditions, and time period of transaction. They concluded that managers should be aware of such factors and their impact on post- 
International Journal of Trend in Scientific Research and Development (IJTSRD) ISSN: 2456-6470

merger/acquisition corporate performance to accurately evaluate proposed offers of mergers and acquisitions and take sound decisions.

Ismail et al. ${ }^{12}$ analyzed the operating performance of selected units of Egyptian companies involved in merger and acquisition (M\&A) during the period 1996 to 2003 in the construction and technology sectors. Empirical results revealed that some measures of corporate performance, such as profitability, suggest statistical significant gains in the years following M\&A especially in the construction sector. Other performance measures as efficiency, liquidity, solvency, and cash flow position did not show significant improvements after mergers in the short run in both sectors. Thus, they concluded that the analysis revealed different results than those of sector level, where total sample analyses indicated that M\&A did not affect the operating performance of the Egyptian merged companies. With respect to sector level, the findings suggested that M\&A in the construction sector contributed in improving firms' profitability but failed to improve efficiency, liquidity, solvency and cash flow position. In the technology sector there was no evidence of improvements in profitability, efficiency, liquidity, etc.

Kar and Soni ${ }^{\mathbf{1 3}}$ analyzed the impact of mergers and acquisitions in the post liberalization period (19912001). In order to empirically analyze the impact, they have taken both macro and micro approach. Firstly, they carried out the comprehensive trend analysis to find trends of mergers and acquisitions for different sectors of the Indian industry and its impact by building a data base of Indian mergers and acquisitions for that period. The impact of mergers and acquisitions on performance has been analyzed by taking a sample of companies broadly representing the different industries. After that they examined the pre-merger \& acquisition and post-merger \& acquisition financial variables for the period of study. They concluded that M\&As have been found to be beneficial in the sense that Indian companies grew in size, and attain better market share which is substantiated by empirical analysis. There has been mixed results for other variables. The nature and pattern of M\&As strategies adopted by the Indian companies reveal mostly horizontal and vertical types. This gives strength to the argument that Indian companies are focusing on their core areas and expanding mostly in related areas of strength which is helpful in realization of synergistic benefits.
Kumar ${ }^{14}$ investigated the post-merger operating performance of a sample of 30 Indian acquiring companies involved in merger activities during the period 1999-2002. He attempted to identify synergies, if any, resulting from mergers. He used accounting data to examine merger related gains to the acquiring firms. He concluded that the post-merger profitability, assets turnover and solvency of the acquiring companies, on average, showed no improvement when compared with pre merger values.

Kumar \& Bansal ${ }^{15}$ tried to understand if the claims made by the corporate sector while going for M\&As to generate synergy, were being achieved or not in Indian context. They did so by studying the impact of M\&As on the financial performance of the outcomes in the long run and compared and contrasted the results of merger deals with acquisition deals. This empirical study was based on secondary financial data and tabulation. Ratio analysis and correlation were also used for analysis. They concluded that in many cases of M\&As, the acquiring firms were able to generate synergy in long run, that may be in the form of higher cash flow, more business, diversification, cost cuttings etc. A limitation of their research was that it showed that management cannot take it for granted that synergy could be generated and profits could be increased simply by going for mergers and acquisitions.

Lau et al. ${ }^{16}$ studied the pre and post merger operating performance of firms in Australia during the period of 1999 to 2004. They compared the post operating performance with the pre-operating performance for both acquirers and targets. Performance measures used in the study were profitability, cash flow, efficiency, leverage and growth. Such measures were used to proxy for the success of the merger, which is defined in terms of an improvement in each merged firm's industry-adjusted operating performance between the pre and post-merger period. The results provided some evidence that mergers improved the post merger operating performance.

Leepsa and Mishra ${ }^{17}$ investigated the trends in merger and acquisition (M\&A) in context with the manufacturing companies in India. They stated that there was no conclusive evidence about the impact of M\&A on corporate performance. They found out that the profitability of the companies has increased in terms of return on capital employed and decreased in terms of return $n$ net worth. And so, the increase has been statistically significant and the decrease has been 
International Journal of Trend in Scientific Research and Development (IJTSRD) ISSN: 2456-6470

statistically insignificant. Hence they concluded that the financial performance of companies improved after merger and acquisition in terms of current ratio, quick ratio, return on capital employed and interest coverage ratio and in terms of return on net worth (RONW) there was statistical improvement.

Mantravadi and Reddy ${ }^{18}$ examined the impact of mergers on the operating performance of acquiring companies in different industries, by examining some pre- merger and post merger financial ratios, with the sample of firms chosen as all mergers involving public limited and traded companies in India between 1991 and 2003. They found that there are minor variations in terms of impact on operating performance following mergers, in different industries in India. They concluded that mergers seem to have had a slightly positive impact on profitability of firms in the banking and finance industry, the pharmaceuticals, textiles and electrical equipment sectors saw a marginal negative impact on operating performance (in terms of profitability and returns on investment). For the Chemicals and Agri products sectors, mergers had caused a significant decline, both in terms of profitability margins and returns on investment and assets.

Pathak ${ }^{19}$ analyzed the post mergers and acquisitions impact on Indian Cement Industry on both the acquiring and target firms. She studied the operating synergy from the perspective of post-acquisition cost efficiencies, rather than the production side efficiencies. She used multiple regression models to capture the synergy effect. She observed that for operational synergy to grow in the cement industry, the intensity of operating expenditure with respect to sales should decrease. Therefore, she concluded that synergy expectations were one of the primary motives that guided M\&As and operating synergy resulted in economies of scale. This reflected indivisibilities and thereby lead to better utilization of capacities after the merger.

Pawaskar ${ }^{20}$ analyzed the pre-merger and postmerger operating performance of 36 acquiring firms during 1992-95, using ratios of profitability, growth, leverage, and liquidity, and found that the acquiring firms performed better than industry average in terms of profitability. He concluded that regression analysis however, showed that there was no increase in the post-merger profits compared to main competitors of the acquiring firms.
Rai ${ }^{21}$ evaluated the stand alone as well as the combined performance of ICICI Bank and Bank of Madura during premerger days. Actual post-merger achievements have been compared with the sum of projections made for each bank using statistical technique as also with the overall figures for the new economy private sector banks. They found that the ICICI Bank remained successful in achieving rapid growth in many respects but could not realize a few expected benefits including the economy of scale. But the positive results outweighed heavily the other aspects making this merger a path-breaker and an example for others. Thus they

Rani, Yadav and Jain ${ }^{22}$ analyzed the short run abnormal returns (AR) to India based mergers by using event study methodology. The short term effects were of interest because of the immediate trading opportunities that they created. They explored the present state of the Indian Pharmaceutical Industry and analyzed some specific cases of acquisitions of foreign companies by the major Indian pharmaceutical companies. They calculated the abnormal returns (AR) and cumulative abnormal returns (CAR) for foreign based acquisitions, mergers and Indian based acquisitions separately and concluded that abnormal returns were highest in case of foreign based acquisitions lowest (negative) for India based mergers.

Ravichandran, Nor and Said ${ }^{23}$ evaluated the efficiency and performance for selected public and private banks before and after the merger in Indian banking sector, as a result of market forces. After doing a factor analysis, they narrowed down the variables for their study to Profit Margin, Current Ratio, Ratio of Advances to Total Assets, Cost Efficiency (ratio of cost to total assets) and Interest Cover and thereafter a regression was run to identify the relationship between these factors and return on shareholders' funds. The results indicated that cost efficiency, advances to total assets and interest cover are significant during both the pre and post-merger phases. Also the returns on shareholders' funds is negatively related to cost efficiency and interest cover but is positively related to ratio of advances to total assets.

Saboo and Gopi ${ }^{24}$ studied the impact of mergers on the operating performance of acquiring firms by examining some pre-merger and post-merger financial ratios of these firms. They also compared the differences in pre-merger and post-merger ratios of 
the firms that go in for domestic acquisitions and international acquisitions. They observed that there were variations in terms of impact on performance following mergers depending on the type of firm acquired - domestic or cross-border. They thus concluded that mergers had a positive effect on key financial ratios of firms acquiring domestic firms while a slightly negative impact on the firms acquiring cross-border firms.

Sinha and Gupta ${ }^{25}$ examined the Mergers \& Acquisitions scenario of the Indian Financial Services Sector. The data for eighty cases of M\&A in the period from March 1993- Feb 2010 was collected for a set of ten financial parameters representing the various characteristics of a firm. They analyzed all the cases individually and collectively to determine the overall effects of M\&A in the industry. They observed that profit after tax (PAT) and profit before dividend, interest, tax and amortization (PBDITA) have been positively affected after the merger but the liquidity condition represented by Current Ratio has deteriorated. Also Cost Efficiency and Interest Coverage had improved and deteriorated in equal number of cases. They concluded that Interest Coverage remains an important factor in determining the return on shareholders' funds both before and after the merger but Profit Margin became important after the merger.

Thambi ${ }^{26}$ analyzed the impact of Mergers on the performance of Indian companies. He evaluated the impact of Mergers on Indian companies through a database of 40 companies selected from CMIE's PROWESS using paired t-test for mean difference for four parameters; Total performance improvement, Economies of scale, Operating synergy and Financial synergy. He concluded that Indian companies were no different than the companies in other part of the world and mergers failed to contribute positively in the performance improvement.

Tse and Soufani ${ }^{27}$ examined the wealth effects on both acquiring and acquired firms using a sample of 124 transactions over the period 1990 to 1996 in United Kingdom. They sub-divided the sample into two merger eras to examine the effect of the prevailing economic performance on the abnormal returns; the first era was Low Merger Activity Era (LMAE) from 1990 to 1993 which was a trough period and included 65 transactions; and the second era was High Merger Activity Era (HMAE) from 1994 to 1996 which was a booming period, it included
59 transactions. The basic testing tool used was "event study" to calculate cumulative abnormal returns (CAR) for both eras. The results indicated that the returns on successful bids in HMAE were positive while returns in LMAE were negative. Marginally, returns in the HMAE were better than those in LMAE. There study suggested a link between the wealth effect and the economic conditions. They thus concluded that gains to target companies (acquired) were mostly positive while those to bidders (acquirer) were debatable.

Vanitha and Selvam ${ }^{28}$ analyzed the pre and post merger performance of Indian manufacturing sector during 2000-2002 by using a sample of 17 companies out of 58 (thirty percent of the total population). For financial performance analysis, they used ratio analysis, mean, standard deviation and t-test. They concluded that the overall financial performance of merged companies in respect of 13 variables were not significantly different from the expectations.

Yeh and Hoshino ${ }^{29}$ examined the effects of mergers on the firms' operating performance using a sample of 86 Japanese corporate mergers between 1970 and 1994. The successfulness of mergers was tested based on their effects on efficiency, profitability, and growth. They made use of total productivity as an indicator of the firm's efficiency or productivity, return on assets and return on equity as indicators of the firm's profitability, and sales and growth in employment to indicate the firm's growth rate. The results revealed that insignificant negative change in productivity, significant downward trend in profitability, significant negative effect on the sales growth rate, and downsize in the workforce after mergers. They concluded that mergers had a negative impact on firm performance in Japan.

Yook ${ }^{30}$ tested the impact of acquisition on the acquiring firm's financial performance by comparing pre and post-acquisition Economic Value Added (EVA) relative to the industry average. His analysis was based on a cross-sectional variation in EVA performance according to the following transaction characteristics namely types of acquisition, methods of payment, and business similarity. The sample comprised 75 of the largest acquisitions that occurred during 1989 to 1994 in the United States. He concluded that acquiring firms experienced significantly deteriorating financial performance after the acquisitions. When calculating industry-adjusted 
International Journal of Trend in Scientific Research and Development (IJTSRD) ISSN: 2456-6470

EVA, the difference is indiscernible, hence, the decline in raw EVA was grounded by industry effects. He also added that, tender offers consistently earned larger EVA than mergers. Hence, larger premiums paid in tender offers can be justified by higher operating performance.

Cabanda and Pajara-pascual (2007) ${ }^{31}$ investigated financial and operating performance of Philippines companies before and after merger and acquisition for the period 1994 to 2003. The study is divided into three time frames (i) 3 years before (ii) 3 years after and (iii) 7 years after merger and acquisition. The study uses conventional accounting and financial approaches in determining the effects of merger on firms' performance. This studied showed mixed results for pre and post merger values. Some measures like acid test ratio, total asset turnover ratio, and net revenues suggest significant gains in long run. Other accounting variable like net income, ROA, net profit margin, capital expenditure/sales, capital expenditure, capital expenditure/total asset, ROS, ROE did not show significant gains after mergers in the short run. They concluded that mergers do not lead to improved performance in the Philippines shipping industry both in short run and long run.

Mantravadi and Reddy (2008) ${ }^{\mathbf{3 2}}$ examined the impact of relative size of the firm on the post merger operating performance. The sample consists all the acquiring transactions happened in the period from 1991 to 2003 in India. The financial ratios employed are operating profit margin ratio, gross profit margin ratio, $\mathrm{NW}, \mathrm{ROCE}, \mathrm{D} / \mathrm{E}$ ratio which covered a period of three years before mergers and five years after mergers. The analysis showed that pre merger operating performance of small sized firms has indicated that relative size does not make any difference to post merger performance. For firms with relative medium size, there were declines in net profit margin ratio and ROCE along with an increase in financial leverage after merger. For firms with relative large size, there was no difference in pre and postmerger performance. For firms where relative size of the target firms was greater than that of the acquiring firm, there was a significant decline in returns on net worth and capital employed and marginal increase in financial leverage.

Daddikar and Shaikh (2014) ${ }^{33}$ investigated the financial performance of jet airways during the post merger and acquisition period specifically in the area of profitability, leverage, liquidity, and capital market standards. They studied the financial performance of jet airways two years before and two years after the merger and acquisition activity. They concluded that there is no statistically significant improvement in surviving company's ROE, net profit Margin, Interest coverage, EPS and dividend per share.

Azhagaiah and Kumar (2011) ${ }^{34}$ investigated the impact of M\&A on Indian manufacturing corporate firms 2 years before and 2 years after covering a period of 2004 to 2010 . They measured the financial performance through $\mathrm{CR}, \mathrm{QR}$, WCTR, ITR, total asset turnover ratio, fixed turnover ratio, gross profit margin ratio, net profit margin ratio, operating leverage, net fixed assets relative to net worth and total liabilities relative to net worth are extensively used. The results computed showed mixed results of pre and post merger and acquisition activity. The study proves that Indian manufacturing corporate firms involved in merger\& acquisition (M\&A) have achieved an increase in the liquidity position, operating performance, profitability, and financial and operating risk. Further, it is inferred that the overall efficiency of acquirer firms is also increased. The statistical analysis also supports for a significant relationship between the pre and post M\&As level of the corporate firms' performance.

Viverita (2008) ${ }^{35}$ studied the impact of merger on commercial bank's performance in Indonesia during 1997 to 2006. Viverita used traditional financial ratios and non parametric data envelopment analysis approach to investigate pre and post-merger performance of banks. The study revealed that merger did increase bank's ability to gain profits. It showed increase in most of performance indicators such as return on asset, return on equity, net interest margin, capital adequacy ratio and non-performing loans. Viverita concluded that merger created synergy as indicates by the statistically and significantly increasing the post-merger financial and productive efficiency performances.

\subsection{Research Methodology}

The research is of descriptive in nature based on the review of leading studies in the area exploring the effects of M\&A on the financial performance of companies before and after Merger and Acquisition. Secondary data is used for this study. The data was obtained from annual leading journals, Articles, reports. The literature was analysed for the content 
International Journal of Trend in Scientific Research and Development (IJTSRD) ISSN: 2456-6470 related to pre and post M\&A performance of firms. The review has been carried out on accounting measuresbased studies and market measures-based studies done at both national as well as international level. An attempt has been made to classify the financial performed indicators into three categories (a) indicators being positively impacted by M\&As, (b) indicators being negatively impacted by M\&As, (c) indicators not being affected by M\&As.

\subsection{Summary of Key researches on M\&A around the world about Pre and Post-Merger Financial Performance.}

\begin{tabular}{|c|c|c|c|c|c|}
\hline S.NO & Author & Year & Sector & Title & $\begin{array}{l}\text { Impact on } \\
\text { Financial } \\
\text { Performance }\end{array}$ \\
\hline 1 & Abbas et al. & 2014 & Banking & $\begin{array}{c}\text { Financial performance of banks } \\
\text { in Pakistan after Merger and } \\
\text { Acquisition }\end{array}$ & Negative \\
\hline 2 & Anand and singh & 2008 & Banking & $\begin{array}{c}\text { Impact of Merger } \\
\text { Announcements on } \\
\text { Shareholders }{ }^{\text {ee }} \text { Wealth: Evidence } \\
\text { from Indian Private Sector } \\
\text { Banks }\end{array}$ & Positive \\
\hline 3 & Beena.S & 2006 & Pharma & $\begin{array}{l}\text { Mergers and Acquisitions in the } \\
\text { Indian Pharmaceutical Industry: } \\
\text { An Exploratory Analysis }\end{array}$ & Positive \\
\hline 4 & P.L.Beena & 2004 & $\begin{array}{l}\text { Comparative } \\
\text { study }\end{array}$ & $\begin{array}{l}\text { Towards understanding the } \\
\text { merger wave in the Indian } \\
\text { corporate sector - a comparative } \\
\text { perspective }\end{array}$ & No \\
\hline 5 & Berg et al & 1982 & $\begin{array}{l}\text { IT, Production } \\
\text { \&Marketing }\end{array}$ & $\begin{array}{c}\text { Joint Venture Strategies and } \\
\text { Corporate Innovation }\end{array}$ & $\begin{array}{l}\text { Negative for } \\
\text { IT and } \\
\text { Positive for } \\
\text { Production } \\
\quad \text { and } \\
\text { marketing } \\
\text { firms } \\
\end{array}$ \\
\hline 6 & Choi and Russell & 2004 & Construction & $\begin{array}{l}\text { Economic Gains around Mergers } \\
\text { and Acquisitions in the } \\
\text { Construction Industry of the } \\
\text { United States of America }\end{array}$ & No \\
\hline 7 & $\begin{array}{l}\text { Cornett, McNutt } \\
\text { and Tehranian }\end{array}$ & 2006 & Banking & $\begin{array}{l}\text { Performance Changes Around } \\
\text { Bank Mergers": Revenue } \\
\text { Enhancement versus Cost } \\
\text { Reductions }\end{array}$ & Positive \\
\hline 8 & Gugler et al. & 2003 & $\begin{array}{l}\text { Comparative } \\
\text { study }\end{array}$ & $\begin{array}{l}\text { The Effects of Merger: an } \\
\text { International Comparison }\end{array}$ & No \\
\hline 9 & $\begin{array}{c}\text { Healy, Palepu, and } \\
\text { Ruback }\end{array}$ & 1992 & $\begin{array}{l}\text { Comparative } \\
\text { study }\end{array}$ & $\begin{array}{c}\text { Does Corporate Performance } \\
\text { Improve After Mergers? }\end{array}$ & Positive \\
\hline 10 & Indhumathi et al. & 2011 & $\begin{array}{l}\text { Comparative } \\
\text { study }\end{array}$ & $\begin{array}{l}\text { The Effect of Mergers on } \\
\text { Corporate Performance of } \\
\text { Acquirer and Target Companies }\end{array}$ & Positive \\
\hline
\end{tabular}


International Journal of Trend in Scientific Research and Development (IJTSRD) ISSN: 2456-6470

\begin{tabular}{|c|c|c|c|c|c|}
\hline & & & & in India & \\
\hline 11 & Ismail et al. & 2011 & $\begin{array}{l}\text { Comparative } \\
\text { study }\end{array}$ & $\begin{array}{c}\text { The Review of Financial and } \\
\text { Accounting Studies }\end{array}$ & Negative \\
\hline 12 & Ismail et al. & 2010 & $\begin{array}{l}\text { Construction } \\
\text { and IT }\end{array}$ & $\begin{array}{l}\text { Exploring Improvements of } \\
\text { Post-Merger Corporate } \\
\text { Performance- the Case of Egypt }\end{array}$ & $\begin{array}{l}\text { Negative for } \\
\text { IT \& Positive } \\
\text { for } \\
\text { Construction }\end{array}$ \\
\hline 13 & Kar and Soni & & $\begin{array}{l}\text { Comparative } \\
\text { study }\end{array}$ & $\begin{array}{l}\text { Mergers and Acquisitions in } \\
\text { India: A Strategic Impact } \\
\text { Analysis for the Corporate } \\
\text { Enterprises in the Post- } \\
\text { Liberalisation period }\end{array}$ & Positive \\
\hline 14 & Kumar & 2009 & $\begin{array}{l}\text { Comparative } \\
\text { study }\end{array}$ & $\begin{array}{c}\text { Post-Merger Corporate } \\
\text { Performance: an Indian } \\
\text { Perspective }\end{array}$ & No \\
\hline 15 & Kumar and Bansal & 2008 & $\begin{array}{l}\text { Comparative } \\
\text { study }\end{array}$ & $\begin{array}{c}\text { The Impact of mergers and } \\
\text { acquisitions on corporate } \\
\text { performance in India }\end{array}$ & Positive \\
\hline 16 & Lau et al. & 2008 & $\begin{array}{l}\text { Comparative } \\
\text { study }\end{array}$ & $\begin{array}{c}\text { Accounting Measures of } \\
\text { Operating Performance } \\
\text { Outcomes for Australian } \\
\text { Mergers }\end{array}$ & Positive \\
\hline 17 & Leepsa and Mishra & 2009 & Manufacturing & $\begin{array}{c}\text { Post Merger Performance : A } \\
\text { Study with Reference to Select } \\
\text { Manufacturing Companies in } \\
\text { India }\end{array}$ & Positive \\
\hline 18 & $\begin{array}{l}\text { Mantravadi and } \\
\text { Reddy }\end{array}$ & 2008 & $\begin{array}{l}\text { Comparative } \\
\text { study }\end{array}$ & $\begin{array}{l}\text { Post-Merger Performance of } \\
\text { Acquiring Firms from Different } \\
\text { Industries in India }\end{array}$ & Positive \\
\hline 19 & Pathak & 2006 & Cement & $\begin{array}{l}\text { A Study of the Operating } \\
\text { Synergy Gains to the Acquiring } \\
\text { \& Target Firms in the Indian } \\
\text { Cement Industry }\end{array}$ & Positive \\
\hline 20 & Pawaskar & 2001 & & $\begin{array}{l}\text { Effect of Mergers on Corporate } \\
\text { Performance in India }\end{array}$ & No \\
\hline 21 & Rai & 2011 & Banking & $\begin{array}{l}\text { Corporate Excellence through } \\
\text { Mergers and Acquisitions: A } \\
\text { Study of ICICI Bank - Bank of } \\
\text { Madura merger }\end{array}$ & Positive \\
\hline 22 & $\begin{array}{l}\text { Rani, Yadav and } \\
\text { Jain }\end{array}$ & 2011 & Pharmaceutical & $\begin{array}{l}\text { Impact of Mergers and } \\
\text { Acquisitions on Shareholders' } \\
\text { Wealth in Short-Run: An } \\
\text { Empirical Study of Indian } \\
\text { Pharmaceutical Industry }\end{array}$ & $\begin{array}{c}\text { Positive } \\
\text { (foreign } \\
\text { based } \\
\text { megers) } \\
\text { negative } \\
\text { (Indian } \\
\text { based } \\
\text { mergers) }\end{array}$ \\
\hline 23 & $\begin{array}{c}\text { Ravichandran, Nor } \\
\text { and Said }\end{array}$ & 2010 & Banking & $\begin{array}{c}\text { Market Based Mergers in Indian } \\
\text { Banking Institutions }\end{array}$ & Positive \\
\hline 24 & Saboo and Gopi & & $\begin{array}{l}\text { Comparative } \\
\text { study }\end{array}$ & $\begin{array}{l}\text { Comparison of Post-Merger } \\
\text { Performance of Acquiring firms }\end{array}$ & $\begin{array}{c}\text { Positive } \\
\text { (domestic) }\end{array}$ \\
\hline
\end{tabular}


International Journal of Trend in Scientific Research and Development (IJTSRD) ISSN: 2456-6470

\begin{tabular}{|c|c|c|c|c|c|}
\hline & & & & $\begin{array}{c}\text { (India) involved in Domestic and } \\
\text { Cross-Border Acquisitions }\end{array}$ & $\begin{array}{l}\text { negative } \\
\text { (foreign) }\end{array}$ \\
\hline 25 & Sinha and Gupta & 2011 & Financial Sector & $\begin{array}{l}\text { Mergers and Acquisitions: A } \\
\text { Pre-Post Analysis For the } \\
\text { Financial Services Sector }\end{array}$ & Positive \\
\hline 26 & Thambi & & $\begin{array}{l}\text { Comparative } \\
\text { study }\end{array}$ & $\begin{array}{l}\text { Impact of Mergers and } \\
\text { Amalgamation on the } \\
\text { Performance of Indian } \\
\text { Companies }\end{array}$ & No \\
\hline 27 & Tse and Soufani & 2001 & $\begin{array}{l}\text { Comparative } \\
\text { study }\end{array}$ & $\begin{array}{l}\text { Wealth Effect of Takeovers in } \\
\text { Merger Activity Eras: Empirical } \\
\text { Evidence from the UK }\end{array}$ & Positive \\
\hline 28 & $\begin{array}{l}\text { Vanitha and } \\
\text { Selvam }\end{array}$ & 2007 & manufactuing & $\begin{array}{c}\text { Financial Performance of Indian } \\
\text { Manufacturing Companies } \\
\text { during Pre and Post Merger }\end{array}$ & No \\
\hline 29 & Yeh and Hoshino & 2002 & $\begin{array}{l}\text { Comparative } \\
\text { study }\end{array}$ & $\begin{array}{l}\text { Productivity and Operating } \\
\text { Performance of Japanese } \\
\text { Merging Firms: Keiretsu-Related } \\
\text { and Independent Mergers }\end{array}$ & Negative \\
\hline 30 & Yook & 2004 & $\begin{array}{l}\text { Comparative } \\
\text { study }\end{array}$ & $\begin{array}{c}\text { The Measurement of Post- } \\
\text { Acquisition Performance Using } \\
\text { EVA }\end{array}$ & Negative \\
\hline 31 & $\begin{array}{l}\text { Cabanda and } \\
\text { Pajara-pascual }\end{array}$ & 2007 & Shipping & $\begin{array}{c}\text { Merger in the Philippines: } \\
\text { Evidence in the Corporate } \\
\text { Performance of William, } \\
\text { Gothong, and Aboitiz (WG\&A) } \\
\text { Shipping Companies }\end{array}$ & No \\
\hline 32 & $\begin{array}{l}\text { Mantravadi and } \\
\text { Reddy }\end{array}$ & 2008 & $\begin{array}{l}\text { Comparative } \\
\text { study }\end{array}$ & $\begin{array}{c}\text { Relative Size in Mergers and } \\
\text { Operating Performance: Indian } \\
\text { Experience }\end{array}$ & $\begin{array}{l}\text { Varied as } \\
\text { per the size } \\
\text { of the firm }\end{array}$ \\
\hline 33 & $\begin{array}{l}\text { Daddikar and } \\
\text { Shaikh }\end{array}$ & 2014 & Aviation & $\begin{array}{c}\text { Impact Of Mergers \& } \\
\text { Acquisitions On Surviving } \\
\text { Firm's Financial Performance: A } \\
\text { Study Of Jet Airways Ltd }\end{array}$ & No \\
\hline 34 & $\begin{array}{l}\text { Azhagaiah and } \\
\text { Kumar }\end{array}$ & 2011 & Manufacturing & $\begin{array}{l}\text { Corporate Restructuring \& } \\
\text { Firms' Performance: An } \\
\text { Empirical Analysis of Selected } \\
\text { Firms of Across Corporate } \\
\text { Sectors in India }\end{array}$ & Positive \\
\hline 35 & Viverita & 2008 & Banking & $\begin{array}{l}\text { The Effect of Mergers on Bank } \\
\text { Performance: Evidence from } \\
\text { Bank Consolidation Policy In } \\
\text { Indonesia }\end{array}$ & Positive \\
\hline
\end{tabular}




\subsection{Key factors that influence financial performance of firms before and after $M \& A$.}

\begin{tabular}{|c|c|c|}
\hline S.NO & Authors & Key Financial Parameters Identified \\
\hline 1 & $\begin{array}{c}\text { Abbas Et Al., Beena.S, P.L.Beena, } \\
\text { Gugler Et Al., Ismail Et Al, Kar And Soni, } \\
\text { Kumar, Kumar And Bansal, Lau Et Al., Leepsa } \\
\text { And Mishra, Mantravadi And Reddy, Pawaskar, } \\
\text { Rai, Sinha And Gupta, Vanitha And Selvam, } \\
\text { Yeh And Hoshino, Cabanda And Pajara- } \\
\text { Pascual, Daddikar And Shaikh, Azhagaiah And } \\
\text { Kumar, Viverita }\end{array}$ & $\begin{array}{c}\text { ROE, EPS,CR,INVENTORY } \\
\text { TURNOVER RATIO,DEBT EQUITY } \\
\text { RATIO, ASSET TURNOVER RATIO, } \\
\text { INTEREST COVERAGE RATIO, } \\
\text { OPERATING PROFIT RATIO, NET } \\
\text { PROFIT RATIO, GROSS PROFIT } \\
\text { RATIO, QUICK RATIO }\end{array}$ \\
\hline 2 & $\begin{array}{c}\text { Tse And Soufani, Rani, Yadav And Jain, Choi } \\
\text { And Russell, Anand And Singh }\end{array}$ & $\begin{array}{c}\text { Market Value, WCAR, The Abnormal } \\
\text { Returns (AR) And Cumulative } \\
\text { Abnormal Returns (CAR) }\end{array}$ \\
\hline
\end{tabular}

\subsection{Summary and Conclusion}

Taking into account the leading studies in the literature that sheds light on the effects of M\&A on the financial performance of companies, these studies used different parameters to evaluate the financial performances of the firms involved in the M\&A activity. Analysis of previous studies reveals:

Most of the studies reveal that banking sector has shown a significant improvement in financial performance after M\&A all over the world (Cornett et al (2006), Rai(2011), Ravichandran(2010), and Viverita(2008))except in Pakistan where the study (Abbas et al, 2014) has shown that M\&As have a Negative impact on financial performance of Pakistani banking sector.

The studies carried out on Pharmaceutical sector have shown that M\&As has positive impact on financial performance (Beena.S, 2006). Moreover, few researchers argue that the impact of M\&As is positive for foreign based mergers and negative for Indian based mergers (Rani, Yadav \& jain,2011).

The comparative studies have shown different results depending upon their geographical locations. Some studies showed No improvement in financial Performance and some studies showed either positive or negative financial performance. Also, the Manufacturing and Construction sector overall has shown positive impact on financial performance after M\&As.

Thus, this paper has reviewed both national as well as international papers in order to link financial performance with M\&A. This paper concludes that the effect of merger and acquisition varies from sector to sector. This paper also shows inconclusive results regarding effect of cross border M\&A and domestic M\&A on the financial performance of the firms. This study also tries to throw light on the importance of M\&A decisions, where they impact the future of the firms businesses. The objective of this paper is to identify the performance parameters and help in understanding how mergers and acquisitions can be more successful.

\subsection{Limitation and Further Research}

i. The significance of various Macro-economic variables on financial performance has not been considered in the above studies.

ii. Most of these studies have been carried out on banking and manufacturing sector, and very few studies have been carried out IT, Pharmaceutical, Aviation. Thus, the significance of these important sectors has been underestimated.

Further research will be conducted on the key accounting factors which were identified through review of literature. Hypothesis will be formulated on 
International Journal of Trend in Scientific Research and Development (IJTSRD) ISSN: 2456-6470

the basis of these key factors. Also hypothesis testing will be done in order to derive the conclusive evidence.

\section{References}

1. Abbas et al.'Financial performance of banks in Pakistan after Merger and Acquisition." Journal of Global Entrepreneurship Research 2014 $4: 13$.

2. Anand, M. and Singh, J. (2008), "Impact of Merger Announcements on Shareholders ${ }^{\text {ee }}$ Wealth: Evidence from Indian Private Sector Banks", Vikalpa: The Journal for Decision Makers 33(1): 35-54.

3. Beena S (2006), "Mergers and Acquisitions in the Indian Pharmaceutical Industry: An Exploratory Analysis", M. Phil Dissertation submitted to the Jawaharlal Nehru University, New Delhi http://mpra.ub.unimuenchen.de/8144/1/MPRA_paper_8144.pdf

4. P.L.Beena, (2004), “ Towards understanding the merger wave in the Indian corporate sector - a comparative perspective", working paper 355, February, CDS, Trivandrum, pp 1-44

5. Berg S.V., J. Duncan and P.Friedman, (1982) "Joint Venture Strategies and Corporate Innovation", Oelgeschlager, Cambridge, MA.

6. Choi, J. and J. Russell, 2004. "Economic Gains around Mergers and Acquisitions in the Construction Industry of the United States of America", Canadian Journal of Civil Engineering 31 (3), pp. 513- 525.

7. Marcia Millon Cornett.,Jamie John McNutt.,and Hassan Tehranian, (2006) "Performance Changes Around Bank Mergers": Revenue Enhancement versus Cost Reductions, Journal of Money, Credit and Banking, Volume 38, Number 4, pp 1013-1050.

8. Gugler, K., D. Mueller, B. Yurtoglu and C. Zulehner, 2003. "The Effects of Merger: an International Comparison", International Journal of Industrial Organization 21, pp. 625653

9. Paul.M, Healy, Krishna Palepu, and Richard.S.Ruback,(1992) "Does Corporate Performance Improve After Mergers?" Journal of Financial Economics, Vol 31, pp 135-175.
10. Indhumathi.G., Selvam.M.,and Babu.M (2011), "The Effect of Mergers on Corporate Performance of Acquirer and Target Companies in India" The Review of Financial and Accounting Studies ISSN 1450-2812 Issue 1.

11. Tariq H.Ismail., Abdulati.A.Abdou and Radwa.M. Annis (2011) "The Review of Financial and Accounting Studies", ISSN 14502812, Issue 1.

12. Ismail, T. H., A. A. Abdou and R. M. Annis, 2010. "Exploring Improvements of Post-Merger Corporate Performance- the Case of Egypt", the Icfai University Journal of Business Strategy (forthcoming).

13. Rabi Narayan Kar and Amit Soni, "Mergers and Acquisitions in India: A Strategic Impact Analysis for the Corporate Enterprises in the Post- Liberalisation period" http://www.igidr.ac.in/money/MERGERS $\% 20$ AND\%20ACQUISITIONS\%20IN\%20INDIA.p df

14. Kumar, R., 2009. "Post-Merger Corporate Performance: an Indian Perspective", Management Research News 32 (2), pp. 145157.

15. Kumar, S., and Bansal, L.K. (2008), "The Impact of mergers and acquisitions on corporate performance in India", Management Decision, 46(10), 1531-1543.

16. Lau, B., A. Proimos and S. Wright, 2008. "Accounting Measures of Operating Performance Outcomes for Australian Mergers", Journal of Applied Accounting 9 (3), pp. $168-180$.

17. N.M.Leepsa and Chandra Sekhar Mishra (2009), "Post Merger Performance : A Study with Reference to Select Manufacturing Companies in India", http://www.internationalresearchjournaloffinan ceandeconomics.com/ISSUES/IRJFE_83_01.pd $\mathrm{f}$

18. Pramod Mantravadi and A. Vidyadhar Reddy, (2008) "Post-Merger Performance of Acquiring Firms from Different Industries in India", International Research Journal of Finance and Economics, ISSN 1450- 2887, Issue 22. 
International Journal of Trend in Scientific Research and Development (IJTSRD) ISSN: 2456-6470

19. Kavita Pathak "A Study of the Operating Synergy Gains to the Acquiring \&Target Firms in the Indian Cement Industry", ICFAI Journal of Mergers \& Acquisitions, Vol. III,NO.4, pp.19-37,December 2006.

20. V.Pawaskar (2001): "Effect of Mergers on Corporate Performance in India," Vikalpa, Vol.26, No.11, January -March, pp 19-32.

21. Dr. Rohan Rai, "Corporate Excellence through Mergers and Acquisitions: A Study of ICICI Bank - Bank of Madura merger", Asian Journal of Technology \& Management Research Vol. 01 - Issue: 01 (Jan - Jun 2011).

22. Neelam Rani.,Surendra.S.Yadav and P.K.Jain, "Impact of Mergers and Acquisitions on Shareholders' Wealth in Short-Run: An Empirical Study of Indian Pharmaceutical Industry" International Journal of Global Business and Competitiveness 2011, Vol. 6, No 1, pp $40-52$.

23. K. Ravichandran., Fauzias Mat-Nor., and Rasidah Mohd Said (2010), "Market Based Mergers in Indian Banking Institutions", International Research Journal of Finance and Economics, Issue 37.

24. Sidharth Saboo and Sunil Gopi, "Comparison of Post-Merger Performance of Acquiring firms (India) involved in Domestic and Cross-Border Acquisitions", http://mpra.ub.unimuenchen.de/19274/1/MPRA_paper_19274.pdf

25. Pankaj Sinha and Sushant Gupta (2011), "Mergers and Acquisitions: A Pre-Post Analysis For the Financial Services Sector", MPRA Paper Number:31253, http://mpra.ub.unimuenchen.de/31253/1/MPRA _paper_31253.pdf

26. Mahesh Kumar Thambi, " Impact of Mergers and Amalgamation on the Performance of Indian Companies" http://128.118.178.162/eps/fin/papers/0506/050 6007.pdf

27. Tse, T. and K. Soufani, 2001. "Wealth Effect of Takeovers in Merger Activity Eras: Empirical Evidence from the UK", International Journal of Economics of Business 8, pp. 365-377.
28. Vanitha, S. and M. Selvam, 2007." Financial Performance of Indian Manufacturing Companies during Pre and Post Merger". International Research Journal of Finance and Economics, 12:7-35.

29. Yeh, T. and. Y. Hoshino, 2002. "Productivity and Operating Performance of Japanese Merging Firms: Keiretsu-Related and Independent Mergers", Japan and the World Economy 14, pp. 347-366.

30. Yook, K.C. 2004. "The Measurement of PostAcquisition Performance Using EVA", Quarterly Journal of Business \& Economics, summer, pp. 67- 84 .

31. Cabanda, E. and M. Pajara-Pascual, 2007. "Merger in the Philippines: Evidence in the Corporate Performance of William, Gothong, and Aboitiz (WG\&A) Shipping Companies", Journal of Business Case Studies 3(4), pp. 87100 .

32. Mantravadi, P. and A. Reddy, 2008. "Relative Size in Mergers and Operating Performance: Indian Experience", Working Paper Series, available at: www.ssrn.com (accessed March 15, 2008).

33. Prasad V. Daddikar and Dr. Arifur Rehman H. Shaikh." Impact Of Mergers \& Acquisitions On Surviving Firm's Financial Performance: A Study Of Jet Airways Ltd", Pacific Business Review International Volume 6, Issue 8, February 2014.

34. Dr. Ramachandran Azhagaiah and T. Sathish Kumar (2011), "Corporate Restructuring \& Firms' Performance: An Empirical Analysis of Selected Firms of Across Corporate Sectors in India", Interdisciplinary Journal of Research in Business Vol. 1, Issue. 4, April 2011(pp.58-82)

35. Viverita 2008, "The Effect of Mergers on Bank Performance: Evidence from Bank Consolidation Policy In Indonesia", International Review of Business Research Papers Vol 4 No. 4 Aug - Sept 2008 Pp.368380 